Article

\title{
Leading from the Niche: Insights from a Strategic Dialogue of Renewable Energy Cooperatives in The Netherlands
}

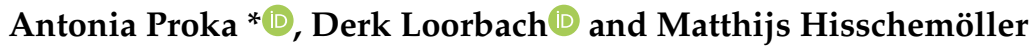 \\ Dutch Research Institute for Transitions, Erasmus University Rotterdam, 3062 PA Rotterdam, The Netherlands; \\ loorbach@drift.eur.nl (D.L.); hisschemoller@drift.eur.nl (M.H.) \\ * Correspondence: proka@drift.eur.nl
}

Received: 16 August 2018; Accepted: 5 November 2018; Published: 8 November 2018

check for updates

\begin{abstract}
Renewable energy cooperatives envision and manifest an alternative way of organising within the energy system (and beyond). Yet, despite their growth, it is uncertain whether such initiatives are able to increase and deepen their impact, leading the transition to an environmentally sustainable and socially just energy system. This paper presents insights from a strategic dialogue co-organised with the Dutch national interest group of renewable energy cooperatives "ODE Decentraal". We used transition management as action research methodology to organise the dialogue to understand and support the transformative potential of the cooperative energy movement. The dialogue helped to clarify the challenges and possibilities for scaling energy cooperatives beyond the niche, supporting at the same time the participants to reflect, strategize and develop a shared transition agenda. This contribution presents and analyses our intervention and its impact, also specifically evaluating the potential of transition management to facilitate social learning processes, reflexivity and the development of strategic actions. Our intervention confirmed the hypothesis that actors in the niche often focus too much on the competition with the regime for individual goals, thereby failing to collectively strategize and engage with incumbent regimes in a systematic way.
\end{abstract}

Keywords: energy transition; renewable energy cooperatives; stakeholder dialogue; backcasting; transition management

\section{Introduction}

The growth of renewable energy cooperatives (RECs) in the Netherlands is driven by dissatisfaction with the state of the energy market, along with financial drives and the wish to contribute to sustainability [1-3]. While only about 20 RECs were active in the country in 2010, in 2017 the field counted about 392 of them, 20\% more than the year before, and the number keeps rising $[4,5]$. RECs envision and manifest an alternative way of organising within the energy system (and beyond), which contrasts with the energy system of our times which is predominantly centralised, market-driven, large scale, and heavily based on fossil fuels. Characterised by a "Do-it-Yourself" culture, RECs self-organise for the establishment of renewable energy projects in their local environment, thereby exploring new ways to organise energy production and consumption on a local scale. In this way, RECs present a niche in the broader context of the ongoing energy transition.

A number of scholars from multiple perspectives have reflected on the nature and role of community energy and the significance of local RECs in the transition towards a sustainable energy system and low-carbon societies (e.g., References [1-3,6-16]. In the economic sphere, RECs may offer economic benefits to their members, while also strengthening the local economies by increasing employment and creating additional business opportunities. In the social sphere, RECs may enhance 
social cohesion, supporting the achievement of common goals through democratic decision-making and resource pooling. In fact, by making the right to renewable energy attainable, RECs activate energy citizenship and realise energy democracy. Lastly, in the environmental sphere, RECs reinforce the energy transition by increasing public acceptance of renewable energy projects and by nurturing a culture of energy conservation through awareness raising and the provision of tools for people to carry out their duty of responsible energy consumption.

Nonetheless, RECs have also received critique regarding their contribution to the energy transition and system change at large. First of all, on certain occasions, RECs have served to reinforce opposition to proposed facilities [15] and despite their potential to enhance social cohesion, RECs may actually also generate social friction and widen pre-existing social divides within communities [15]. In fact, RECs have been accused of only taking care of their members' interests (at the cost of society), and that, over time, they accommodate to the practices of the capitalist market in order to survive.

The transformative potential of RECs, the potential of having a fundamental impact upon the established regime, remains unclear. Previous research has shown that such initiatives lack a shared direction and coordination, as well as the capacity to interact in a strategic way with the dominant regime [e.g. 9,10,13,14,16]. Specifically, in the case of the Netherlands, Proka et al. [16] found that renewable energy initiatives, including but not limited to RECs, exhibit the ambition but lack a clear strategy on how to increase their impact upon the regime. In the context of a dominant regime where the power is concentrated in a few hands, the scholars register a lack of unity among the different initiatives, as well as a lack of a clear position vis-à-vis the regime [16]. In practice, this lack of coordination between them, results in higher variety of specific initiatives, but may also be seen as fragmentation in the renewable energy sector, which may undermine its prospects to grow.

Such problems in achieving diffusion beyond the niche level comprise one of the central topics of the field of sustainability transitions research. While favourable conditions at the landscape and regime-level are considered necessary, an actual transition implies that new technologies, practices and structures become mainstream. By definition, in a context that increasingly opens up to adopt mainstream alternatives, this implies that tensions will emerge at the niche-level, where change agents develop and protect these alternatives by investing (often all of their) time and energy to nurture and develop them.

Within a context of increasing systemic transformation in the energy system, a rapid decrease of prices of renewables and their subsequent diffusion, and rapidly increasing policy commitments, investments and engagement of incumbent business, the question that arises is whether the cooperative energy movement could develop its strategic capacity to diffuse its vision beyond the niche to proactively influence the direction and pace of the energy transition in the Netherlands. Such an ability to mobilise people towards a common vision through the encouragement of aligning their own interests with that of a collective has been referred to as leadership [17] (see also References [18,19] on transformational leadership). The previous question can thus be rephrased as follows: can the cooperative energy movement take leadership in the energy transition in the Netherlands? This question becomes pertinent as there are realistic possibilities that regime actors seek to control the energy transition, its pace and direction by suppressing the values and principles presented by the cooperative movement (democratic, transparent, just, sustainable). On the other hand, it is also possible that the actors from the cooperative energy movement lack the strategic capacity to move beyond their day-to-day competition with the regime for individual goals, in order to engage in a more impactful way with it.

With the aim to understand, and potentially support, the transformative potential of RECs, we have organised, together with the national interest group of renewable energy cooperatives "ODE Decentraal", a dialogue for the deployment of a medium-term strategy (2018-2025) with an extension to 2030. Specifically, in developing the strategic dialogue, we sought to explore this twofold challenge: How to better understand the possibilities and challenges that actors within the niche face in their interaction with the regime, and how to facilitate the development of a strategic joint agenda for the Dutch cooperative movement. The dialogue followed a transition management approach, which is 
a practical governance framework that helps analyse and stimulate systemic change by facilitating scientific reflection and insight in transition dynamics, actor perceptions and strategies [20,21]. In so doing, transition management simultaneously helps the actors themselves to reflect about their own role and develop visions, strategies and interventions in their contexts [20,21].

From a transition research perspective, the process helped to deepen our understanding of the dilemmas that actors face in scaling beyond the niche and the possibilities of using transition concepts and tools to empower them. Such concepts include questions relating to the willingness and ability of niche actors to cooperate, and the possibilities to align individual goals and values or the space for collective strategizing. Our intervention specifically explored the following sub-questions:

1. What is the contribution of the cooperative movement to the energy transition at large?

2. What barriers and opportunities emerge in the attempt of moving beyond their niche?

3. What governance interventions — and by whom — can help to facilitate this?

The purpose of this paper is to present and analyse the outcomes of the strategic dialogue, also reflecting upon the ability of transition management to build reflexive and strategic capacity through social learning Here, with social learning we refer to a process in which people exchange and discuss knowledge and ideas about what they perceive as reality, and as a result, they get new insights, develop shared mental models, form new relationships, and develop the capacity for collective action [22]. In fact, the time interval since the organised strategic dialogue, enables us to assess the impact of our intervention on the processes of the RECs also considering their spin-off activities.

In what follows, first comes a short history of the cooperative movement within its institutional framework in the Netherlands (Section 2), followed by a presentation of our research approach and methodology including its theoretical foundations (Section 3). We proceed with the direct outcomes of the dialogue: (a) the identity of the cooperative energy movement and its shared (quantitative) vision regarding its contribution to wider energy transition; (b) the identified barriers and opportunities for pursuing this vision; and (c) the concrete strategic vision of the movement for 2025-2030, along with the implications for governance interventions (Section 4). Section 5 reflects upon the dialogue from an action research perspective to abstract insights into (a) barriers and mechanisms to scaling transformative alternatives beyond the niche; (b) the indirect (social learning) effects of transition management processes by considering the activities undertaken by the initiatives pursuing the drafted action plan. Section 6 draws conclusions and presents possible future research avenues.

\section{Background: The Cooperative Energy Movement and Its Institutional Context in The Netherlands}

The Dutch energy regime is deeply connected to the fossil fuel industry. Since the discovery of large natural gas reserves in Slochteren in 1959, gas revenues have, directly and indirectly, been an important factor in the national budget [23]. Although the level of importance is changing, up to the present, the Dutch treasury has significantly depended on revenues from tax on energy products like natural gas, electricity and motor fuels, whose consumption are principal drivers of climate change, and the balance between raising a "green revenue" and achieving a "green result" is quite delicate [24]. This balancing act is also reflected in the country's policymaking. The main support schemes for renewable energy production in the Netherlands involve net-metering, a premium-tariff and a more recent tax-relief arrangement. As Proka et al. [16] point out, the Dutch regime supports sustainable energy innovations in so far as they are instrumental for meeting its climate goals, but it also safeguards that its dominance is not jeopardised. Indicative of this is that while the government establishes support schemes for renewable energy, its natural gas production continues.

Since the discovery of the natural gas field, energy has been seen as an economic commodity to be exploited by the state [25]. While foreign energy intensive companies were attracted to the Netherlands because of the low energy prices, the national government sought little involvement in how energy production develops [25]. Electricity and gas provision were taken care of by regional companies 
owned by municipalities and/or provinces, while the gas sector enjoyed the provision of the national gas grid by the state [25]. At that time, while gas allowed for the substitution of coal, the government expected that nuclear power would be the future [25].

After the oil crisis in the 1970s, Dutch society was faced with its strong dependence on the foreign import of fossil fuels. The dominant discourse of economic growth and technological opportunities was challenged by voices of anarchism, feminism, and radical environmentalism [25]. In the context of emerging concerns about the environment, the public discourse initially focused on the undesirability of nuclear energy (vis-à-vis nuclear waste, safety and radiation concerns), slowly shifting towards green alternatives and energy saving [25]. Within such a context, a number of bottom-up initiatives begun to emerge. Among them, the first RECs appeared in the late 1980s; the focus was on wind energy. The 1989 Electricity Act gave grid access to the RECs, also guaranteeing a standard price, and the early 1990s noted a moderate increase in the number of local initiatives. This increase was attributed to a mix of environmental concerns and the wish for local independence and income for the local community [1]. The liberalisation of the energy market in the Netherlands that followed (late 1990s and early 2000s) brought additional opportunities for the RECs, as energy suppliers could profile themselves as "green". The emerging initiatives were different from the previous wind cooperatives, as the new wave was dedicated to collectively saving, producing and also supplying green energy [1,25]. Their motto appears to be "energie van, voor en door ons zelf", i.e., energy from, for and by ourselves. As major energy companies got fully privatised, the new cooperative movement embodied "a reaction to scaling up, privatization and liberalization of the energy sector" (p. 57) [25].

The recent developments concerning the country's gas reserves creates a window of opportunity for (another) change in the Dutch energy system. As the supplies coming from North Sea fields have declined (in 2017 the Netherlands became a net importer of natural gas) and protests against natural gas extraction have risen, the government proclaims a change of strategy [26]. Specifically, in March 2018, after more than 900 homes were damaged in early January when the province of Groningen was hit by a 3.4-magnitude earthquake, the Dutch government announced it would cut production at the Groningen gas field to 12 billion cubic meters per year by 2022, and to zero by 2030 [26]. This opens space for alternative (sustainable) energy niches to gain importance and compete for establishing their propositions on how energy production, distribution, and consumption should be organised. The cooperative energy movement embodies one of these alternative energy niches. The next section presents the research approach and methodology employed for exploring whether the cooperative energy niche can take leadership in the Dutch energy transition.

\section{Research Approach and Methodology}

\subsection{Sustainability Transitions and Transition Management}

Sustainability transitions research focuses on the processes of systemic change, like the energy transition, and how they unfold $[27,28]$. Transitions have been described as "evolutionary revolutions" that emerge over decades [29]. According to the theory, transitions come about as the result of processes at multiple levels: external changes and trends at the landscape level, encompassing exogenous factors like demographic, political and economic change, puts pressure on incumbent regimes, the dominant functioning of the system, thereby causing internal tensions, which enable the increasingly competitive alternative configurations, emerging in niches, to gain momentum and break through $[30,31]$. Innovations emerging in niches, can gain momentum by growing legitimacy and access to resources by articulating precise visions, crucial for acquiring the support of networks of (powerful) allies [32].

While transition theory does not exclude the possibility of a niche outcompeting the regime through direct confrontation and rupture, a transition typically takes off when, under the pressure of regime destabilization, proactive regime actors start to collaborate with actors from the niche (cf. [33]). This requires both sides to be able to work beyond existing networks and routines, but also to 
contribute to change beyond one's own community or direct environment. Therein, an orchestrating shared orientation and discourse is crucial for the coordination of all agents interested in institutional change, i.e., change of the dominant institutions [34]. The latter are understood here as "the formal and informal (explicit or implicit) rules of the game that shape the behaviour of actors in society" (p. 14) [35].

Transition management is a governance approach and a form of action research that uses analytical transition concepts to identify persistent problems, niche-regime dynamics and potential seeds and dynamics of transition. It provides a framework to develop transition-based governance strategies, through instruments such as transition arenas, transition scenarios, transition experiments, and transition monitoring [27]. By providing the principles for a participatory process with actors selected based on their involvement in a system and their interest to contribute to transitions, transition management stimulates reflexivity, social learning and strategic agency for transformative change $[20,21]$.

During the process, transition researchers synthesize discussions, select core insights and ideas and facilitate the dialogue towards a shared strategic agenda. The undertaken activities involve: (a) an opening process of problem structuring and backcasting (see Box 1) for the development of a vision that generates a sense of urgency; (b) the development of coalitions, images and transition agendas that suggest a course of action; (c) the mobilisation of people to achieve this vision through the implementation of projects and experiments; and (d) a process of evaluation and monitoring [20,34,36].

Box 1. Participatory Backcasting.

Backcasting is a participatory approach proposed for addressing issues of long-term system change.
In contrast to forecasting approaches, where pathways to a future state are developed incrementally starting
from the present, backcasting first identifies a future end-point radically different from the present, and, then
works back to the present [37,38]. Encouraging reflection and 'out-of-the-box' thinking, backcasting is useful in
investigating complex problems and addressing far-reaching changes [39,40]. Backcasting helps to visualise
long-term transformations, and identify the involved pathways of high uncertainty [41]. Crucial for strategizing,
this method allows for exploring the implications of alternative pathways and the values that underlie them, as
well as the feasibility of the alternative developed visions, along with the required interventions for reaching
them $[39,42,43]$.

The sequence of steps leads to a shared transition agenda (direct output), and as the actors internalize and adopt this agenda as their own, the process facilitates social learning (indirect output). Such processes also help to test assumptions and uncover more details and insights vis-à-vis the initial transition analysis, as the sessions ease surfacing tacit knowledge from participants.

\subsection{Process Design and Analysis: Operationalising the Transition Management Principles}

The transition team started its process in September 2016 (see also Table 1). For designing the transition arena, the transition team had thorough strategic discussions on the problem, the context, whom to involve, and what the learning goals should be. The specific goals of this transition arena have been the creation of: (1) a shared understanding of the dynamics within the renewable energy niche and how they relate to the broader energy system; (2) a shared sense of direction and empowerment (understood here as the intrinsic motivation and the belief that one can direct specific actions towards desired ends [44]) and (3) the development of collective reflexive and strategic capacities in general. In that, the process aimed to facilitate the collective reflection on internal drivers, motivations and commonalities across different individual RECs and to support the generation of strategic ideas for future development and engagement with the energy regime. When exploring the ongoing dynamics and possibilities for supporting the transformative potential of the initiatives, the focus has been not only on technological, but also on broader institutional aspects, as identified by Proka et al. [16,45].

The broader underlying assumption for our intervention has been that a transition management process could facilitate social learning, reflection and the development of collective agendas by synergizing individual goals. It has been expected that a shared understanding of the origin, nature 
and dynamics of transitions in certain societal domains will empower actors to prepare and better adapt to such dynamics in order to influence their speed and direction [46]. Additionally, the transition team formulated a number of hypotheses to be explored at the arena. First of all, it was hypothesised that the actors operating within the niche are too occupied with their own activities to be able to develop the strategic capacities needed to transform the regime. We assumed that by highlighting synergies between different niches, a strategic vision could enable them to engage with the regime more effectively. In fact, in line with Reference [47], we expect that a vision can help RECs attract new actors and more resources. Nevertheless, difficulty to bridge different niches has also been anticipated.

Table 1. Overview of the transition management phases (Adapted from [36]).

\begin{tabular}{|c|c|c|}
\hline Phase & Process Steps & (Main) Actor Setting \\
\hline $\begin{array}{l}\text { 1. Setting the scene } \\
\text { 2. Exploring system dynamics }\end{array}$ & $\begin{array}{l}\text { Formation of the transition team } \\
\text { Setting up the process plan } \\
\text { System and actor analysis }\end{array}$ & Transition team \\
\hline $\begin{array}{l}\text { 3. Framing the transition challenge } \\
\text { 4. Envisioning a sustainable system } \\
\text { 5. Reconnecting long- and short-term }\end{array}$ & $\begin{array}{c}\text { Problem definition } \\
\text { Designing a transition vision } \\
\text { Developing transition pathways and a } \\
\text { transition agenda }\end{array}$ & Transition arena \\
\hline 6. Engaging and anchoring & $\begin{array}{l}\text { Disseminating transition agenda and } \\
\text { engaging new actors and networks } \\
\text { Implementation of radical short-term } \\
\text { actions (transition experiments) in line with } \\
\text { the transition agenda }\end{array}$ & Transition network \\
\hline
\end{tabular}

Following an official invitation, persons who expressed interest to participate were interviewed about the idea of organising a strategic dialogue to assist the bottom-up energy movement. In this interview, they were also asked to suggest other potential participants. Through this snowball technique, in total 22 people were identified and invited. After the interviews and within group communication, 15 out of those 22 people committed to participation. This group consisted of representatives of RECs, cooperatively developed energy suppliers, as well as the national knowledge platform of ODE-Decentraal. In one case, the transition team had to retract an invitation, as several other invitees declared they would not be able to speak out freely and take part with an open mind in case of the participation of a representative of a commercial wind and solar project development company.

The team drafted "rules of the game", encompassing the roles and responsibilities of all parties involved. In terms of confidentiality, the process followed the Chatham House Rule: participants are free to use the information obtained in the dialogue, but they may not disclose the specific source of the information, the affiliation of the source or that of other dialogue participants. Moreover, the rules made clear that full consensus was not sought; instead, diverging arguments were welcomed. During the process, the transition team shared and shifted between the roles of process facilitator, knowledge broker, reflective and self-reflective scientist, and change agent [48].

The dialogue took place between December 2016 and mid-March 2017. Despite the fact that the original planning of the dialogue spread longer, the national elections (on 15 March) played a catalytic role for accelerating the process. Participants wanted to be ready to use the dialogue outcomes in the negotiation process for a new government. The first meeting focused on the development of an ambitious qualitative and quantitative vision. The second meeting explored the opportunities and barriers for realising the cooperative vision through solar, wind (onshore and offshore) and sustainable heating projects. After the second meeting, dialogue participants organised an additional meeting aimed at the "translation" of the identified opportunities and barriers into policy proposals for the to-be formed new government. During the final meeting, in March, the discussion focused on elements of a strategic vision and the further development of a number of governance and policy interventions 
for strengthening the feasibility of attaining it. The dialogue was therefore concluded at the fifth phase of transition management, as presented in Table 1.

To facilitate the data analysis, the meetings were transcribed, and based on the transcriptions; reports were prepared and circulated among the participants for verification and additional input. Next, the findings were discussed between the authors, and analysed. At the end of the dialogue, a report was compiled for advice on the cooperative energy movement. Last but not least, an evaluation questionnaire was distributed among the participants. The evaluation involved questions about what worked well and what could work better in the dialogue, as well as questions regarding the dialogue's impact on (i) the participants' daily practices, (ii) networks and (iii) principles and values.

\section{Outcomes of the Strategic Dialogue}

\subsection{Towards a Strategic Vision}

\subsubsection{Identity of the Cooperative Energy Movement and Its Potential Contribution}

The focus of the first meeting was on reflecting about the internal dynamics within the cooperative energy sector and specifically on illuminating the vision of the initiatives about their collective future. The discussion focused on three elements, the very identity of the movement, expectations with respect to their potential contribution to and share of total Dutch energy production and consumption, and the increased social support as shown by membership figures.

Participants described their movement with the concept of energy democracy. Energy democracy was understood as a political, economic, social, and cultural concept that links the technical characteristics of the energy transition to citizen participation and democratic control. The RECs claim that by facilitating the transition to a sustainable system, they bridge the gap between investment, production and consumption of energy, while giving back to the end-users the ownership and control over the energy being a public good. End-users (e.g., citizens or companies) become (co-)owners of their energy supply. Cooperative energy projects need to be sustainable, decentralised, and transparent.

For the dialogue participants, the energy transition is about more than just energy: it is about a more equal distribution of resources and power. The cooperative approach integrates environmental and social concerns by tackling urgent energy issues, while pursuing systemic change. Therefore, the energy transition may help the creation of a new type of economy where the financial resources for energy stay in the community and get re-invested according to the local needs. In this way, the renewable energy capacity installed in their environment strengthens the local communities and, in fact, the energy transition may become a vehicle for wider system change.

For this to happen, three levels for the involvement of people in a cooperative were distinguished. One level is the transactional, when one becomes a customer of a cooperative. Another level is the relational, when one gets a share or provides a loan to a cooperative for the development of a project. The third level, is the goal-oriented, when people actually share a vision and the aspiration to meet a specific goal. It has been argued that all levels are crucial for a "deeper and longer-term connection with members". Although this point has been debated, in general the cooperative energy movement in the Netherlands is oriented towards combining ownership of RES with prosumption, yet this is not always possible.

This ambition for institutional change was considered the basic difference between RECs and renewable companies on a commercial basis. For the RECs, money is important for having the systemic impact they aspire. As one of the participants put it: "the cooperatives need money to make the transition, while they (i.e., commercial initiatives) need the transition to make money". It was argued that when the RECs pursue profit, it is "profit-for-purpose".

A key element of this purpose is their contribution to the energy transition through the development of renewable energy projects. By 2017, almost 1 Peta-Joule (PJ), equal to about 278,000,000 kWh, was cooperatively generated in the Netherlands, almost entirely through wind [46]. This is a negligible $0.05 \%$ of the net Dutch energy demand. Dialogue participants pointed out that 
the energy transition had just started and that RECs still have a "petty" image and make "baby steps". However, the initiatives have the ambition to professionalise, which will make the acceleration exponential. Participants shared their initial expectations regarding the cooperative potential in terms of renewable electricity, heating and energy savings. It turned out that these expectations considerably diverged, many being overly optimistic. The exercise led to a choice of parameters for a quantitative end vision, i.e., (1) total production of cooperative energy, (2) energy savings, (3) cooperative share in total national production and consumption, (4) cooperative share in total production of renewables, (5) cooperative share in total solar and wind, and (6) cooperative share of total energy demand by households.

Since the energy transition beyond kWhs involves people, participants in the dialogue also expressed their expectations about future membership of RECs. The majority of people are not interested in the issue of energy; as pointed by one of the participants, a great number of people "have never changed their energy provider". Thus, mobilising people either as members, co-workers or simply customers is considered difficult.

The views presented by the dialogue participants in terms of the cooperative renewable energy production and/or membership, varied widely. From this wide range, the transition team chose two points in time ( 2025 \& 2030) for drafting an overarching vision for the field. This quantitative vision was consolidated at a later stage.

\subsubsection{Quantifying the Vision}

The vision was quantified through iterations between the dialogue participants and the researchers. Based on the discussions so far, the transition team drafted an ambitious quantitative vision regarding the contribution of the RECs to the Dutch energy transition. A first draft, with an ambition for 2030, was met with the response that it contained "too many numbers". Therefore, a second, medium-term vision was developed for 2025, which zoomed in on a few parameters, especially the one linking cooperative share of total energy demand by households. This would enable the dialogue to link numbers on energy to the issue of membership size, i.e., to link the sustainable energy targets to the broader social, economic and political targets of the cooperative energy movement.

The central question for framing the 2025 vision was: "When will the cooperative movement in the process of upscaling have reached the point of becoming part of a renewable energy regime"? This question was translated into two quantitative questions: (1) Which membership size would be needed to realise a breakthrough for the cooperative movement? (2) How much energy needs to be produced or saved to at least substantially meet the membership's energy demand? The political power and influence of the movement will definitively increase as the membership size grows.

By now, the joint RECs have about 50,000 members [49]. RECs work mostly together with smaller renewable energy-oriented companies, and most of their membership increase corresponds to the clientele loss of larger energy incumbents. Therefore, to determine the necessary upscaling of membership we looked into the clientele of some large energy companies in the Netherlands. RWE and Vattenfall are the biggest with 3 and 2 million household customers; Eneco (still) owned by municipalities, follows with about 2 million customers; and other medium size companies have between 150,000-500,000 private customers [50-52]. Based on this information, the vision suggested a membership size of 1 million by 2025, implying a yearly membership increase of $50 \%$.

To meet the total household energy demand (including heat and electricity) of 1 million prosumers, about 10 billion $\mathrm{kWh} /$ year will be needed, which equals $36 \mathrm{PJ}$ renewable electricity annually. If these people were also to switch to electric driving, energy demand will increase by one third to $47 \mathrm{PJ} /$ year. Part of this demand will still be covered by utilities and part of the cooperative production would be sold to other clients (industry, other companies, sports clubs, etc.). Households may cover about half of their energy use by cooperative production, about $25 \mathrm{PJ}$ (about 7 billion $\mathrm{kWh}$ ). It is also envisioned that 200,000 members of RECs will have switched to renewable heating. It is assumed that with efficient heat pumps this will lead to energy savings up to $5 \mathrm{PJ}$ (about 1.4 billion $\mathrm{kWh}$ ). 
This means that after subtraction of savings, cooperative production of renewable energy must increase from $1 \mathrm{PJ}$ by now to $20 \mathrm{PJ}$ in 2025 (about 5.6 billion $\mathrm{kWh}$ ), which is about $10 \%$ of net energy consumption in the Netherlands [53]. To realise $20 \mathrm{PJ}$ in 2025, cooperative production must rise 1/3 per year. This vision looks extremely ambitious for the RECs, but the number of $20 \mathrm{PJ}$ is still moderate when total Dutch consumption is taken into account; in fact, this amount appears low as compared to expectations of some dialogue participants.

To determine the share of wind and solar we looked into the growth rate of cooperative production over recent years. Cooperative wind now covers about $1 \mathrm{PJ} /$ year. The growth rate has been moderate, about $10-20 \%$ a year, which is for large part explained by obstructive policies of several provincial governments against on-shore wind (see also [16]). The vision assumes a more supportive stance because of pressures on the Netherlands to realise its climate targets. Therefore, for wind, an annual growth rate of $30 \%$ is envisioned sufficient to realise 9.6 PJ in 2025.

The share of cooperative solar in the Netherlands is currently $0.07 \mathrm{PJ}$, which is still negligible. However, the growth rate of solar projects is much higher than wind, between $250 \%$ and $300 \%$ per year. Estimating with an annual growth rate of $75 \%$, cooperative solar will by 2025 cover 10.7 PJ. So, basically it is envisioned that half of the cooperative production would be sourced through wind and half through solar. Without necessarily committing to this vision, at this point, dialogue participants agreed to use it as a starting point in the actual backcasting.

\subsection{Identification of Barriers and Opportunities}

During the second meeting of the strategic dialogue, the participants discussed the possible barriers and opportunities for the cooperative deployment of renewable electricity (solar and wind) and heat in the Netherlands. The identified issues are several and interconnected. The elaborate lists of issues as identified per technology may be found in the Appendix A.

\subsubsection{Solar \& Wind Energy}

Concerning barriers, the dialogue participants principally focused on issues originating in the policy domain, as well as on issues of competition with national or international commercial actors. With respect to the deployment of solar energy, although the postal code tax relief scheme ("postcoderoos" in Dutch), that national policy introduced in 2013, is generally perceived as complex, the main policy barrier comes from municipal regulations. In the case of wind projects, national and provincial regulations are more important. The participants stress that the existing competition is intensified by the low availability of roofs and other surfaces, due to the unwillingness of their owners to provide them; a barrier in itself. The representatives of RECs reflected upon their level of professionalization, especially in relation to (offshore) wind project development, and the collective image of the community (described as "petty" or "petite bourgeois"), and how both factors may inhibit their progress. The fact that energy is a "non-issue" for the majority of people has been described as a significant barrier; the public lacks both the interest and the awareness around the urgency of the energy transition. Indicative is that the opposition to wind projects often relates to an impression that there is already "enough" onshore wind. The role of RECs is, thus, not only to provide renewable electricity to some, but to involve and engage people on a deeper level, as argued by some of the dialogue participants.

Regarding opportunities, the situation in Groningen, brought to the fore by the recent earthquake in 2018, emerges as a catalytic factor for the transition to renewables. Beyond this, the dialogue participants discussed the expected benefits of the professionalization of the sector and the establishment of coalitions. The local municipalities have been identified as key actors, as they could support them with several mechanisms, such as guarantees, low interest loans, or the provision of their roofs/land for project development. For the latter, partnerships with locals have been considered valuable in general. The RECs could mediate between them and electricity end-users to develop projects (and receive a financial return). Furthermore, the technological domain involves extra opportunities as the initiatives could adjust their projects for heat or e-mobility services. To give 
more context on the above barriers and opportunities (whose whole list is presented in Tables A1 and $\mathrm{A} 2$ in the Appendix A), we next zoom in on some parts of the discussion.

First of all, regarding their challenges with public authorities, the participants agreed that, especially for wind energy, "Government is an obstacle", as one participant pointed; often this is true at the municipal and provincial level too. In fact, RECs are not (yet) in the consciousness of aldermen or other officials. As one participant describes: "already three years ago, I was talking to the municipality, about the fact that we could provide them with our energy. Well, that was seen as a good idea, but it took another two years ... and it has not gotten through yet... " Only in some places is this alliance present; some municipalities have already given priority to RECs for the development of wind in their area.

The professionalization of the initiatives for the development of more and bigger projects brought up elaborates discussions. While it was pointed that "members' growth is important for us to be able to realise things (i.e., projects) and realising things is important to get this members' growth", especially relevant in the case of wind projects, the dialogue participants expressed their concerns about whether the movement has the capacity to pursue them. Specifically, some participants argued that developing offshore wind demands significant financial resources and expertise that even the cooperatives with long experience in onshore wind development lack. Yet, others pointed out that this area should not be left to (multinational) commercial developers, because in this way, resources collected from every energy consumer (through the energy tax) will be channelled to powerful companies. It was actually argued that more trust should be placed on the knowledge of the local community: "I think those fishermen know exactly where the wind is ... they know those places... I think your fishermen know a lot more about the North Sea than The Hague (where the government is located)."

Beyond their own capacity (or lack thereof), the discussion also touched upon the issue of public acceptance of renewables and the role of RECs in democratising the energy system. The issue arose when discussing the recent emergence of small-scale "village" wind turbines in the country. While such turbines may seem as a "friendlier" alternative, they are inefficient, which even intensifies, the issue of space, and while it was suggested that more locations may become available for them, others pointed out that resistance may actually increase due to the fact that these wind turbines would need to be positioned closer to people's vicinity. It is exactly there that the role of RECs is crucial. As pointed, being active in a cooperative "you determine yourself as a neighbourhood where a wind turbine does or does not come ... That is beautiful; that there is a cooperative that says, we are going to decide where our limit is. That is energy democracy!"

In fact, the discussion specifically focused on the role of RECs in mobilising people for renewables, as well as on the ideal level of involvement. The question has been if the cooperative movement has solely become a vehicle for project developers to go through the permit procedure, or whether it has succeeded in establishing "prosumption", linking production and consumption of renewables. Nowadays, not all RECs employ a business model where the investors or owners of the sustainable installations can actually use the self-generated energy. This relates to choices made in the (recent) past and the availability of certain support schemes. In the discussion, some suggested that renewable energy production does not need to be directly connected to consumption. Instead, it was stressed that production should ensure visibility. It was argued that especially wind energy projects have an enormous capacity to mobilise people and capital for achieving substantial sustainable energy generation within sight distance. "The interesting thing about what we are doing is that I have people (as members) who develop their roots in the region and derive pleasure from it. For me it is not about realising production out of view, because then we become exactly the same as Shell, who are also in full production." Yet, others pointed out that visibility is not enough; for some participants it is crucial to link a project's financing with a concrete transaction. "There is one reason why a cooperative succeeds, the same reason is why a cooperative fails: that is linking financing and transaction", adding "you do not invest because you receive money from the wind turbine, but because you receive power from the wind turbine... As soon as we start making it possible for people to become customers and not members, as long as one may invest without receiving electricity, then it goes wrong." It is explained that the involvement at a transactional level 
does not last long, and renewing it requires a high marketing budget, which local RECs lack. This is why the relational level is important, strengthened by a goal orientation. "Tackling those 3 levels, the transactional, relational and goal-oriented, makes a cooperative strong." This is seen as "the real strongest unique selling point" of the initiatives. Nevertheless, some participants questioned that RECs should always pursue such deep member involvement. This links back to the discussion about the purpose of the movement. "What is bad about having double objective? Democratisation and sustainability?" It was argued that collaborating with an "impact investor" that consciously wants to invest in a cooperative project is not bad. "I think that the strong focus on the ideal model is a threat for the movement". While this tension has not been completely resolved, the working compromise was that even when the deep involvement of people appears to be the "ideal", not all RECs need to aim for it.

Lastly, among the several opportunities that were discussed for the growth of the movement and the transformation of the energy system, one related to the possibility of expanding the activities of RECs across the value chain. Starting from the fact that solar panels are usually imported from China, and wind turbines from Denmark, some dialogue participants argued that the movement could initiate its own factories in the Netherlands. Actually, for some, RECs should take care of the production, financing, as well as the installation of the renewable energy infrastructure. For this, cooperation and coordination is necessary, and as it has been pointed: "Deltawind is not going to set up a construction company on its own, nor will the Windvogel. That risk is too high, but if we share the risk together, we may ultimately have a construction company together, which may facilitate services for our members." However, opposition to this point also emerged as other participants argued that the movement should not become a "club" that does everything alone. Instead it should seek the collaboration with other actors of the "big society". In relation to this, a tension that emerged involved the trade-offs regarding the possible support of local suppliers vs. taking advantage of economies of scale through partnerships with bigger suppliers.

\subsubsection{Sustainable Heat}

The discussion on the barriers and opportunities for the transition to sustainable heat differed from the discussions on energy from wind and solar, not only due to its different nature (i.e., different technologies, different kind of service, etc.), but also due to the lower level of experience of the dialogue participants with it. In what follows, we discuss some major issues. (See Table A3 in the Appendix A for the complete list).

Starting with the barriers, the most significant involve the preference of the public authorities for centralised top-down solutions, the lack of transparency on possible development of heat network(s) and the related costs, the technological difficulties and the increased financial costs as such (especially for rural contexts), the unclear business model, as well as the very limited experience of the cooperative with the deployment and management of heat projects. In fact, although RECs would wish to keep (full) control and responsibility over the heat networks, they acknowledged their difficulty to tackle the issue completely autonomously. Materialising heat projects through community initiatives is difficult due to the shortage of people with the required expertise. Establishing partnerships is therefore vital for advancing the heat transition. Given its experience, the role of the grid operator was seen as central; network operators have, in part, already taken the lead in the transition away from natural gas. Nonetheless, several issues hinder such a collaboration. Principal is, for instance, the lack of transparency regarding network costs, which inhibits the assessment of the affordability of different heating solutions.

On the other hand, the public gas debate, intensified by the earthquakes and the house damages in Groningen, along with the forthcoming possible dependence on the unstable Russian regime, creates a window of opportunity for radical change in the system of heat provision throughout the country. For this, sufficient non-food biomass, including waste-water and sewage sludge, is available in a large part of the country. Moreover, small-scale heat installations, as well as heat installations belonging to housing associations, do not require a special heat supply permit from the Authority for 
Consumers and Market, which makes them a good fit for the transition to decentralized heat projects. The downturn of the construction industry appeared as another opportunity for the RECs to advance the heat transition. The initiatives could link up with construction companies to push for energy efficiency upgrades of buildings; past experiences of housing cooperatives may be useful. For instance, the coalition could combine the provision of house renovations with that of vacation packages for their owners. Additionally, the dialogue participants suggested that building international partnerships, by collectively getting involved in the pellet factory of the Belgian cooperative Ecopower, for example, could also support the heat transition in the country.

Although several barriers and opportunities have been identified by the dialogue participants, during the dialogue, the barriers for the energy transition have not been discussed in length. Instead of a detailed analysis of the problem, the discussions principally explored different possibilities for future action. This solutions-orientation may be attributed to the characters of the specific dialogue participants, but may also comprise a commonality across actors engaged in the niche. We will reflect upon this further in Section 5.

\subsection{The Strategic Vision of the Movement and the Implications for Governance Interventions}

The direct outcome of the dialogue process was a consolidated vision and an action agenda with several tactical measures for attaining it. This section presents the concrete vision for the Netherlands and some of the tactical measures of more relevance for the cooperative movement as a whole.

\subsubsection{The Strategic Vision of the Cooperative Energy Movement}

The dialogue participants converged on an ambitious vision regarding the contribution of the RECs on the Dutch energy transition. Specifically, the RECs pledge to realise $25 \mathrm{PJ}$ (7 billion $\mathrm{kWh}$ ) of sustainable energy production and savings in the Netherlands by 2025. This may be translated to:

- $\quad$ sustainable heat for 200,000 households: this equals to energy savings of more than 5 PJ (1.5 billion $\mathrm{kWh}$ );

- generation of electricity through more than 10 million solar panels (of an average capacity of $300 \mathrm{Wp}$ ): this yields more than $10 \mathrm{PJ}$ (3 billion $\mathrm{kWh}$ );

- generation of electricity through 250 wind turbines (of an average capacity of $5 \mathrm{MW}$ ): this also yields around $10 \mathrm{PJ}$ ( 3 billion $\mathrm{kWh}$ ), and,

- the involvement of 1 million households in a cooperative either as an investor or as a buyer of collectively generated electricity or heat.

In April 2017, this vision was published by ODE Decentraal [54]. The vision is important because, functioning as an anchor point for strategy and communication with a broader audience, it supports the movement's collective agency. The insights into what a possible sustainable energy future could look like, and the established transition agenda which is presented next, also creates a feeling of legitimacy for engaging with the regime, and may enable the movement to take leadership in its transformation.

\subsubsection{Action Agenda}

To make a greater contribution to the sustainability of the Dutch energy supply, participants acknowledged that the RECs will have to get involved in many more and especially larger decentralised projects. At present, too little expert manpower is available for this. They recognised that the organisational structure and management capacity of the RECs is far from ideal and to improve it, the following measures have been decided: (a) a Development Fund through which the preliminary phase of (large) projects can be (pre-) financed; (b) a course for training and education for people who want to contribute to project development and management of RECs; and (c) a certification scheme for local RECs aimed to prevent proliferation and commercial misconduct.

When it comes to the policy recommendation to the authorities, the agreed action points may be located at the national and local level. First of all, at the national level, the participants call for 
the national government to facilitate an energy awareness campaign, which could be co-developed with civil society organisations, citizens and businesses. With regards to the existing regulations, it was suggested that the postal code tax relief scheme should shift to an "area scheme", allowing in this way for the cooperative development of more solar and wind projects (See also Reference [16]). The development of wind energy, specifically, should take place collaboratively on areas where it is socially acceptable, and RECs should also be given the opportunity to (co-) exploit wind at sea. Special attention should be given to (the consequences of) the heat transition, for which the Dutch cooperative movement has presented its concrete proposition for a gas-free future in the Netherlands [55]. Specifically, the movement calls for the establishment of goals at the regional level and the deployment of energy allocation plans ("energiebestemmingsplannen" in Dutch) to meet them. The cooperative energy movement supports an integrated approach to energy on land and participatory development within the Environmental Vision ("Omgevingsvisie" in Dutch). Moreover, the need for a more decentralised sustainable energy supply and the application of energy storage options, calls for a national review of the energy transport cost structure, as well as the cost of local energy storage; therein, network operators could play a major role. Furthermore, the national government can stimulate the cooperative movement by contributing to a Development Mechanism to finance the risky development phase of larger cooperative projects for wind, solar, heat and energy saving.

At the local level, provinces can make an important contribution to the energy transition by facilitating the spatial application of decentralised energy generation. Instead of complicating the process for the RECs, by limiting, for instance, the possibilities for (replacing existing) wind turbines, the local provinces should create provincial investment funds for renewable energy to (partially) cover the risks of investments undertaken by RECs. Moreover, municipalities which own land should (preferably) provide them for cooperative development. If they are not landowners themselves, municipalities should enforce cooperative development, for instance, by stating that a developer should always work with 50\% involvement of a local cooperative. By making municipal land and roofs available, the municipalities may give RECs a chance to participate in large projects. Moreover, municipalities may bring companies in contact with local RECs in their area. Discounts on municipal taxes for the companies that provide their land or roofs, for instance, could function as an encouragement for making more business roofs available for solar panels. Lastly, municipalities can also arrange that RECs borrow money at the lowest possible interest rate from the country's promotional bank of and for local authorities and public sector institutions.

The developed vision and transition agenda should not be seen as an end in itself (prediction of the collective future of the community of RECs) but as a means to influence this future. The dialogue participants have come up with several ideas that could directly improve their current situation. However, the timing of the dialogue (close to the national elections) resulted in much of the attention of the participants to be directed to short-term measures, mostly towards the to-be-formed national government. Therefore, it could be argued that the representatives of RECs only partially managed to distant themselves from the present to look at the broader picture of the energy transition. The drafted agenda, nevertheless, needs not to be 'implemented' as a blueprint, but it may be adopted in bits and pieces by the dialogue participants and a mobilised network of change actors. Next, we reflect upon these findings and our overall research process.

\section{Insights into Empowering Transformative Leadership from the Niche}

Our intervention aimed to foster leadership aimed at the sustainable transformation of the energy system by facilitating the development of reflexive and strategic capacities through social learning. Here we reflect on this goal from an action research perspective. First, we discuss the direct and indirect (social learning) effects of our research, and then we reflect upon the role of transition management therein.

To identify the main effects of the dialogue on the participants and the development of the cooperative renewable energy niche, we go back to our strategic dialogue goals, which may function 
as an evaluation framework. Overall, the dialogue resulted in a shared understanding about the past, present and future of the cooperative movement in the context of the energy transition. Our empirical involvement confirms our assumption that so far the initiatives have been too busy pursuing their own individual goals to be able to develop collective strategic capacities. In fact, the dialogue process concluded with the co-organising and participating umbrella organisation ODE Decentraal publishing the movement's ambition accompanied by a list of specific measures to attain it [54], as well as a statement about the cooperative contribution to the heat transition in particular [55]. The former document consolidates the problem framing, with ideas for short- and long-term actions necessary for the transition to a sustainable energy system democratically operated and managed. In that, this document is an attempt to address the identified in the strategic dialogue institutional and organisational lock-in mechanisms.

Specifically, the identified lock-in mechanisms are located both in the institutional and organisational sphere. First of all, policy is mostly protecting the incumbents and its change is slow, both at the local and national level. At the local level, where the interaction with the initiatives is more direct, the established cultural beliefs and cognitive routines (of aldermen) appear to be inhibiting, as RECs are most often not acknowledged as legitimate partners in the energy transition. In fact, the image of RECs seems to limit the diffusion of the cooperative model in the energy domain, and this may relate to the fact that the level of engagement that the initiatives promote contrasts with the current lifestyles. Lastly, apart from lack of economies of scale, organisational lock-ins appear to be significant too. To be precise, the overall level of professionalization, the lack of experience with certain sectors (offshore wind and heat), as well as the difficulty to deepen and broaden their networks, are factors that undermine the development of the sector.

In their evaluation of the dialogue process, some of the participants pointed out that the narrative gives them a sense of direction and helps them to orient their actions and choices more strategically. Yet, for others, the process was too inward-looking; as one participant argued the dialogue process was "a lot about what we want, and find important, rather than what people, who do not have that same drive", and indeed the participants did not manage to sufficiently distance themselves from their personal positions to identify all the bottlenecks for the transition and how they could pragmatically be addressed. Although this may be attributed to the idealistic features of the actors involved in the cooperative energy field, it may also come as a result of the specific dialogue design. We will get back to this when discussing our research methodology.

The strategic dialogue has supported raising the awareness among the dialogue participants regarding the identity of the cooperative energy movement in the Netherlands and the plurality of approaches within it. The cooperative energy movement integrates principles regarding the environmental aspects of sustainability (i.e., green energy) but also social aspects, like active citizenship and self-determination. While these values seem to be easily combined, certain tensions emerge when practically applying them. Specifically, while all actors aspire towards the transition to a "green" energy system, and may also cherish the possibilities for the democratisation of the energy system that the cooperative approach brings, no unanimity exists about the idea of using the energy transition as a vehicle for reclaiming people's power and re-establishing a social economy. This tension relates to the discussion about the movement's unique quality summarised in the words "Van, Voor, en Door" i.e., energy of the people, for the people and by the people. For some, "the challenge is not to further professionalise our project development power, but to organise solidarity within the area we operate (and to receive pre-financing)". Yet, while some voices stress the importance of aiming for deep involvement of membership at all three levels-the economic (transaction), social (relational) and environmental (sustainability-oriented) —arguing that this unique value can offer an attractive perspective to Dutch consumers, no consensus about it has been reached. Instead, what was established is a basic understanding and respect for the different approaches which may be employed in parallel. In fact, it is coordination that the movement needs, not unity. In a form of cultural pluralism, the different RECs may co-exist with each other, considering the particularities of the sub-groups, as 
enriching to the overall qualities of the movement; and indeed, as the cooperative movement will need to address in the near future a broader group of people with various desires and interests, this multitude of values and approaches may be beneficial.

Another impact of the dialogue relates to empowerment. The process enabled the actors to feel legitimate and able to contribute to the energy transition, also by taking new roles. This resulted in several spin-off activities: The creation of an administrative program for the RECs; the establishment of an association for the participation of RECs in offshore wind; the bundling of the different lobby and knowledge development organisations of the field; some organised attempts for inquiring funds for the professionalization of the cooperative energy sector; the establishment of a local solidarity fund, as well as the development of wind maps and the first steps to include them in local Environmental Plans. The maturing of the cooperative field was also exhibited, when, a year after our dialogue process, the ministry announced the measures it was planning to take to support the energy transition. Overall, the announced measures were aligned with the wishes of the cooperative movement. Yet, the suggestion for a parallel increase of the natural gas tax and decrease of the electricity tax, aimed at shifting consumption from one to the other, received negative reactions from several individual RECs which argued that this measure will kill the movement as it is making the development of projects with the tax-relief arrangement extremely risky, if not unfeasible. Nevertheless, the umbrella organisation ODE-Decentraal officially acknowledged the possible positive impulse of the measure on the overall transition, pointing out that actions will be taken to reduce the nuisance that the tax adjustment brings to the movement [56]. At this point, it should be clarified that we cannot be certain about the level of impact of our intervention on the above; in fact, we do not know if the same activities would have taken place even without the organised strategic dialogue.

Lastly, we wish to reflect on transition management as an action research methodology, and the ability of the research process to facilitate developing leadership. Our role was to design and facilitate the dialogue process, to quantify the cooperative vision and to compile all the reflections and governance propositions in a report oriented towards the empowerment of the cooperative movement. Interestingly, despite the fact that our invitation was originally directed towards multiple actors from the bottom-up, (the majority of) the invited actors from the cooperative energy movement preferred to discuss strategy among peers only, excluding other parties. This may confirm our hypothesis regarding the difficulty of bridging different niches. However, such a decision by the participants may have been influenced by our approach which, by involving a lot of representatives of RECs from the beginning, was leaned too much towards the cooperative energy niche. By avoiding broadening the meetings to additional participants, an opportunity was lost for the creation of new networks beyond the cooperative energy niche, something that had been expected to strengthen the prospects of a regime transformation. Actually, by excluding other actors, the dialogue participants missed the opportunity to discuss their ideas with people with different perspectives, which could better prepare them for the interaction with the regime. Nevertheless, the existing networks began to deepen through the creation of trust and mutual respect. This inward orientation may also indicate that, despite the emergence of some structures (e.g., for knowledge dissemination or energy supply), the cooperative movement in the Netherlands is still in its infancy. Coordination among peers may therefore be a legitimate first step before the engagement in broader strategic discussions.

Although certainly not perfect, the followed process offered multiple insights into the renewable energy cooperative movement, while also supporting its development. The dialogue participants fully endorsed the quantitative vision drafted through the dialogue process. In fact, their umbrella organisation ODE Decentraal, co-organising the strategic dialogue, shared it widely. At the same time, it should be stressed that while the timing of the elections may have helped mobilising more people to participate in the dialogue and share their knowledge and experience, the conditions may have hindered the ability of people to think strategically on a longer time-horizon. Furthermore, we argue that the role of transition management in bringing tensions to light is significant. As a framework that facilitates reflection, transition management can contribute in surfacing existing tensions, which 
can be valuable for helping to avoid a possible future escalation. In this, the role of facilitation is crucial. Facilitation should help create understanding and respect of the different positions, setting the foundations for coordination of action between different approaches. On a different note, looking at the last meeting of the dialogue, we may also recognise our responsibility in not having facilitated the dialogue participants in linking the numerous activities envisioned to a certain timeline. This may in fact be a rather difficult effort as it involves negotiation of priorities.

\section{Conclusions}

Our contribution has facilitated the cooperative energy movement to develop an overarching orientation towards the cooperative ownership and control of renewable energy infrastructure and the shift to conscious energy prosumption. The challenges are many, but so are the different opportunities presented for the movement to take advantage of. The dominant energy regime in the Netherlands, comprised by only a few parties responsible for the electricity, heating and transport solutions, has been trying to find ways to remain in power. In such a context, while functioning under absolute unity contradicts with the very nature of direct action initiatives, and may even compromise the prospects of their spreading, coordination among the RECs is critical. Therein, the contribution of our strategic dialogue is important as the detailed action plan drafted appears to have already enabled the initiatives to operate in alignment with their collective strategic vision.

Transition management proved to be a useful approach to create a direct impact by helping to develop reflective and strategic capacities, and create a more nuanced understanding of the challenges and difficulties of moving beyond the niche. Our experiences illustrate that it is possible to combine direct societal impact with a research agenda on advancing sustainability transitions. The positive societal impact of the dialogue process has been the creation of a narrative, the deepening of the network, and a sense of direction, also empowering towards more transformative action. Future research could expand the focus of this intervention by pursuing a broader stakeholder dialogue, also involving other actors, and possible partners of the cooperative energy field. Further research could also assess the prospects and value of establishing a collaborative business model between RECs and hybrid actors such as the network operators.

By engaging in such a dialogue as researchers, this also highlights tensions around normativity and prescriptivity in research. Our experience is that through the dialogue we were able to get more in-depth empirical insights and a better understanding of a number of theoretical ideas and assumptions. Future research could compare and contrast the observations presented here (on both research content and process) with insights from different research approaches on the study of RECs, thereby enriching such observations and possibly also developing the research approach.

Author Contributions: All authors were involved in the design of the research, the investigation and the preparation of this manuscript. As the principal investigator, the first author prepared the original draft. Both co-authors reviewed and edited this draft, which was then revised by the first author. The first author was also responsible for the overall project administration of the strategic dialogue.

Funding: This work has been supported by the Netherlands Organisation for Scientific Research (NWO) under the research programme “TRAPESES" (2014-2018); grant number 408-13-029.

Acknowledgments: First and foremost, we want to thank all the practitioners who participated in the strategic dialogue; we have learned a lot in this process and we are happy to have been of support to the cooperative energy movement. We would like to also thank Sjors Overbeke for his assistance during the dialogue process. Next, we would like to thank the participants of the 2018 IST conference in Manchester and those of the 2018 SASE conference in Kyoto for their valuable comments on earlier versions of this paper. We are also thankful to the two anonymous reviewers of this journal for their constructive feedback.

Conflicts of Interest: The authors declare no conflict of interest. 


\section{Appendix}

Table A1. Identified barriers and opportunities for solar energy.

\begin{tabular}{|c|c|}
\hline Barriers & Opportunities \\
\hline $\begin{array}{l}\text { Policies and political power } \\
\text { Municipality level: } \\
\text { - Lack of supportive municipal policies } \\
\text { - Municipal procurement rules focus on lowest price } \\
\text { National/international level: } \\
\text { - Lack of govt. ambition for } 2030 \\
\text { - Lack of flexibility of tariffs } \\
\text { - Risk of ending Premium tariff scheme (Stimulating } \\
\text { Renewable Energy production, "Stimulering van } \\
\text { Duurzame Energieproductie" in Dutch (SDE+)) } \\
\text { - Risk of limiting SDE+ scheme to large projects }\end{array}$ & $\begin{array}{l}\text { Policies and political power } \\
\text { Municipality level: } \\
\text { - Procurement rules: price-quality balance } \\
\text { - Guarantees } \\
\text { - Affordable loans by local govt. funding agency } \\
\text { - Active ground (“Actief grondbeleid" in Dutch) /roof } \\
\text { - Risk funds } \\
\text { National/international level: } \\
\text { - Separate category in SDE + for RECs } \\
\text { - Tax system permits } \\
\text { - Alignment with political parties } \\
\text { - Link to EU Emission Trading Scheme for } \mathrm{CO}_{2} \\
\text { - Sustainable energy as a public task }\end{array}$ \\
\hline $\begin{array}{l}\text { Technology and infrastructure } \\
\text { Physical environment: } \\
\text { - Low availability of roofs due to low willingness of } \\
\text { owners to provide them } \\
\text { - Possible negative impact on network stability }\end{array}$ & $\begin{array}{l}\text { Technology and infrastructure } \\
\text { Physical environment: } \\
\text { - Focus on roofs } \\
\text { - Blockage on onshore wind } \\
\text { Technological development and innovation: } \\
\text { - Stronger, cheaper, integrated: e.g., solar roof } \\
\text { tiles/windows, floating panels, boilers for cooling } \\
\text { - Energy storage, local energy system management }\end{array}$ \\
\hline $\begin{array}{l}\text { Sector structure } \\
\text { Competition: } \\
\text { - Competition from larger commercial players } \\
\text { (professional trusts) } \\
\text { - Lack of portfolio } \\
\text { - Increased cost due to focus on quality } \\
\text { - Avoidance of risk capital \& liability } \\
\text { - Avoidance of venture capital } \\
\text { - Competition with agricultural land and } \\
\text { other functions }\end{array}$ & $\begin{array}{l}\text { Sector structure } \\
\text { Certification of RECs } \\
\text { Alliances: domestic and international, "multi-stakeholder } \\
\text { organisations" } \\
\text { Integration of a sustainable system: } \\
\text { (1) Horizontal integration: } \\
\text { - Wind, solar connection with heat for buffering } \\
\text { - Linking to other functions (car, house) } \\
\text { - Services delivery to companies } \\
\text { (2) Vertical integration: } \\
\text { - Expansion of activities across value chain: solar panel } \\
\text { manufacturing, installer, construction, bank, collective } \\
\text { purchase, etc. } \\
\text { - Employment opportunities }\end{array}$ \\
\hline
\end{tabular}

Organisational logic

- Difficulty to engage members and involve new Opposition:

- Not-in-my-back-yard (NIMBY) attitude

- Resistance to large-scale projects

Image:

- Petty image (petite-bourgeois)

- Internal disagreements

- Low diversity of people

\section{Organisational logic}

People mobilisation (engagement \& involvement):

- (1) Transactional; (2) Relational; (3) Goal oriented

- Learning through local networks

- Strategy: (1) focus on community more than energy,

(2) ownership of Energy infrastructure, Data and Money

- Communication through social media

"Sun yield" as a pension 
Table A2. Identified barriers and opportunities for wind energy.

\begin{tabular}{|c|c|}
\hline Barriers & Opportunities \\
\hline $\begin{array}{l}\text { Policies and political power } \\
\text { - Government as an obstacle } \\
\text { - Long waiting list for locations }\end{array}$ & $\begin{array}{l}\text { Policies and political power: } \\
\text { - Daring decision making } \\
\text { - Exclusive support from municipalities } \\
\text { - Local energy projects for regional (spatial) development }\end{array}$ \\
\hline \multirow[t]{2}{*}{$\begin{array}{l}\text { Technology and Infrastructure } \\
\text { High costs }\end{array}$} & $\begin{array}{l}\text { Technology and Infrastructure } \\
\text { - Technological development and innovation: e.g., } \\
\text { large-scale solar in combination with wind } \\
\text { - Smaller wind turbines }\end{array}$ \\
\hline & $\begin{array}{l}\text { Sector structure } \\
\text { - Expansion of activities across value chain } \\
\text { - Quota in offshore wind deployment (e.g., } 50 \% \\
\text { cooperative) }\end{array}$ \\
\hline $\begin{array}{l}\text { Organisational logic } \\
\text { Internal resources } \\
\text { - Low expertise, (few) volunteers } \\
\text { - Difficult mobilisation of people } \\
\text { Role-image } \\
\text { - Risk of being seen only as an investment group } \\
\text { Business case } \\
\text { - Too heavy to involve membership } \\
\text { - Insufficient capital among residents }\end{array}$ & $\begin{array}{l}\text { Organisational logic } \\
\text { Professionalization } \\
\text { Use of the positive synergy between wind projects and } \\
\text { people mobilisation } \\
\text { People mobilization through focus on low energy costs } \\
\text { Legitimacy } \\
\text { - Tipping point when above } 1000 \text { members } \\
\text { - Exemplar projects for more status } \\
\text { - Municipalities as customers }\end{array}$ \\
\hline \multirow[t]{2}{*}{$\begin{array}{l}\text { Knowledge base } \\
\text { - Lack of (in-sector) knowledge on offshore wind } \\
\text { - Lack of public awareness \& interest: energy as a } \\
\text { "non-issue", limited belief in techn. feasibility of RES, } \\
\text { feeling of abundance of wind turbines on land }\end{array}$} & \\
\hline & $\begin{array}{l}\text { Landscape level } \\
\text { Urgency due to Groningen earthquakes }\end{array}$ \\
\hline
\end{tabular}

Table A3. Barriers and opportunities for sustainable heat.

\begin{tabular}{ll}
\hline Barriers & Opportunities \\
\hline \multirow{3}{*}{ Policy and political power } & Policy and political power \\
- Priority given to top-down planning instead of a & Municipalities: \\
bottom-up democratic process & - Energy plan, Energy zoning plan \\
- General requirement of a heat supply permit from & - Environmental/ambient plan ("omgevingsplan" in Dutch) \\
Authority for Consumers and Markets & - Allowing customisation per neighbourhood/ postal code \\
- Lack of protection against the heat law & Small-scale installations and/or installations belonging to \\
& (housing) owners association do not require heat supply \\
& permit from the Authority for Consumers and Markets \\
\hline & Technology and Infrastructure \\
& Technical development and innovation: \\
& - Variation local sources: pellets, manure, residual heat \\
Technology and Infrastructure & (also fossil), green gas through current gas infrastructure \\
Difficulty of energy saving & - National availability of non-food-competitive biomass, \\
& like sewage and sewage sludge \\
& - Thermal heating energy storage \\
& - Possibility for very small-scale heat networks \\
& - Possible use excess electricity for heating \\
& Collective heat solutions are easier than individual \\
\hline
\end{tabular}


Table A3. Cont.

\begin{tabular}{|c|c|}
\hline $\begin{array}{l}\text { Sector structure } \\
\text { Dubious role of network operator } \\
\text { - Lack of clarity about the installation of heating } \\
\text { networks across the country }\end{array}$ & $\begin{array}{l}\text { Sector structure } \\
\text { Alliances: } \\
\text { - Cooperation with experienced network operators } \\
\text { - Cooperation of RECs and fund for early phase } \\
\text { development } \\
\text { - Partnership with Belgian cooperative Ecopower vis-à-vis } \\
\text { acquiring shares of their pellet factory }\end{array}$ \\
\hline $\begin{array}{l}\text { Organisational logic } \\
\text { - Unclear business model } \\
\text { - Little choice: package approach (monopoly) } \\
\text { - Lack of people: impossibility of fast increase of } \\
\text { membership } \\
\text { - Petty image (petite-bourgeois) }\end{array}$ & $\begin{array}{l}\text { Organisational logic } \\
\text { Business model } \\
\text { - Offer more control to tenants } \\
\text { - Collective arrangement is easier than individual } \\
\text { - Improved financial return for energy saving } \\
\text { Idleness of building/construction industry opens space for } \\
\text { action for RECs }\end{array}$ \\
\hline
\end{tabular}

\section{Knowledge base}

Awareness

- Low awareness about necessity and feasibility of transition

- Luck of awareness about the issue of heat and the potential of its cooperative management Impediment in thinking:

- Priority given to top-down planning instead of bottom-up democratic process

- Public fear of the "unknown"

- "Trias energetica" (i.e., sustainable energy in three steps: (a) reduce energy loss; (b) maximise use of sustainable sources; (c) make efficient use of fossil-fuel based energy sources) as a barrier

\begin{tabular}{ll}
\hline Landscape level & Landscape level \\
Vast majority of people are not in line with the & - Urgency due to Groningen earthquakes \\
bottom-up development of heating solutions & - Anti-gas movement Off the gas ("Van het gas af" in Dutch) \\
& - International dependency on Russia \\
\hline
\end{tabular}

\section{References}

1. Oteman, M.; Kooij, H.J.; Wiering, M.A. Pioneering Renewable Energy in an Economic Energy Policy System: The History and Development of Dutch Grassroots Initiatives. Sustainability 2017, 9, 550. [CrossRef]

2. Van Der Schoor, T.; Scholtens, B. Power to the people: Local community initiatives and the transition to sustainable energy. Renew. Sustain. Energy Rev. 2015, 43, 666-675. [CrossRef]

3. Van Der Schoor, T.; Van Lente, H.; Scholtens, B.; Peine, A. Challenging obduracy: How local communities transform the energy system. Energy Res. Soc. Sci. 2016, 13, 94-105. [CrossRef]

4. Schwencke, A.M. Lokale Energie Monitor 2015. Burgers participeren in energie Resultaten en impact van de burgerenergiebeweging; HIER Opgewekt: Utrecht, The Netherlands, 2015. (In Dutch)

5. Schwencke, A.M. Lokale Energie Monitor 2017; HIER Opgewekt: Utrecht, The Netherlands, 2017. (In Dutch)

6. Walker, G.; Cass, N. Carbon reduction, 'the public', and renewable energy: Engaging with socio-technical configurations. Area 2007, 39, 458-469. [CrossRef]

7. Walker, G.; Devine-Wright, P. Community renewable energy: What should it mean? Energy Policy 2008, 36, 497-500. [CrossRef]

8. Rogers, J.C.; Simmons, E.A.; Convery, I.; Weatherall, A. Public perceptions of opportunities for community-based renewable energy projects. Energy Policy 2008, 36, 4217-4226. [CrossRef]

9. Seyfang, G.; Hielscher, S.; Hargreaves, T.; Martiskainen, M.; Smith, A. A grassroots sustainable energy niche? Reflections on community energy in the UK. Environ. Innov. Soc. Transit. 2014, 13, 21-44. [CrossRef]

10. Seyfang, G.; Park, J.J.; Smith, A. A thousand flowers blooming? An examination of community energy in the UK. Energy Policy 2013, 61, 977-989. [CrossRef]

11. Smith, A.; Hargreaves, T.; Hielscher, S.; Martiskainen, M.; Seyfang, G. Making the most of community energies: Three perspectives on grassroots innovation. Environ. Plan. A 2015, 48, 1-26. [CrossRef] 
12. Dóci, G.; Vasileiadou, E. Let's do it ourselves Individual motivations for investing in renewables at community level. Renew. Sustain. Energy Rev. 2015, 49, 41-50. [CrossRef]

13. Yildiz, Ö.; Rommel, J.; Debor, S.; Holstenkamp, L.; Mey, F.; Müller, J.R.; Radtke, J.; Rognli, J. Renewable energy cooperatives as gatekeepers or facilitators? Recent developments in Germany and a multidisciplinary research agenda. Energy Res. Soc. Sci. 2015, 6, 59-73. [CrossRef]

14. Hasanov, M.; Zuidema, C. The transformative power of self-organization: Towards a conceptual framework for understanding local energy initiatives in The Netherlands. Energy Res. Soc. Sci. 2018, 37, 85-93. [CrossRef]

15. Tarhan, M. Renewable Energy Cooperatives: A Review of Demonstrated Impacts and Limitations. J. Entrep. Organ. Divers. 2015, 4, 104-120. [CrossRef]

16. Proka, A.; Hisschemöller, M.; Loorbach, D. Transition without Conflict? Renewable Energy Initiatives in the Dutch Energy Transition. Sustainability 2018, 10, 1721. [CrossRef]

17. Weathersby, G.B. Leadership vs. management. Manag. Rev. 1999, 88, 5.

18. Burns, J.M. Leadership; Harper and Row: New York, NY, USA, 1978.

19. Bass, B.M. Leadership and Performance beyond Expectations; Free Press: New York, NY, USA, 1985.

20. Loorbach, D. Transition management for sustainable development: A prescriptive, complexity-based governance framework. Governance 2010, 23, 161-183. [CrossRef]

21. Loorbach, D. Transition Management: New Mode of Governance for Sustainable Development. Ph.D. Thesis, Erasmus University Rotterdam, Rotterdam, The Netherlands, 2007.

22. Beers, P.J.; Van Mierlo, B. Reflexivity and learning in system innovation processes. Sociol. Rural. 2017, 57, 415-436. [CrossRef]

23. Rijksoverheid. Rijksoverheid Miljoenennota 2017: Nota over de Toestand van 's Rijks Financiën; Ministry of Finance: The Hague, The Netherlands, 2016.

24. Vollebergh, H. Green Tax Reform: Energy Tax Challenges for The Netherlands; PBL Netherlands Environmental Assessment Agency: The Hague, The Netherlands, 2014.

25. Kooij, H.J.; Oteman, M.; Veenman, S.; Sperling, K.; Magnusson, D.; Palm, J.; Hvelplund, F. Between grassroots and treetops: Community power and institutional dependence in the renewable energy sector in Denmark, Sweden and The Netherlands. Energy Res. Soc. Sci. 2018, 37, 52-64. [CrossRef]

26. Simon, F. Europe Grapples with Dutch Gas Collapse. EURACTIV.com. 2016. Available online: https://www. euractiv.com/section/energy/news/europe-grapples-with-dutch-gas-production-collapse/ (accessed on 30 May 2018).

27. Loorbach, D.; Frantzeskaki, N.; Avelino, F. Sustainability Transitions Research: Transforming Science and Practice for Societal Change. Annu. Rev. Environ. Resour. 2017, 42, 599-626. [CrossRef]

28. Markard, J.; Raven, R.; Truffer, B. Sustainability transitions: An emerging field of research and its prospects. Res. Policy 2012, 41, 955-967. [CrossRef]

29. Rotmans, J.; Kemp, R.; van Asselt, M. More evolution than revolution: Transition management in public policy. Foresight 2001, 3, 15-31. [CrossRef]

30. Kemp, R.; Schot, J.; Hoogma, R. Regime shifts to sustainability through processes of niche formation: The approach of strategic niche management. Technol. Anal. Strateg. Manag. 1998, 10, 175-198. [CrossRef]

31. De Haan, J. Towards Transition Theory. Ph.D. Thesis, DRIFT, Erasmus University Rotterdam, Rotterdam, The Netherlands, 2010.

32. Geels, F.W.; Raven, R. Non-linearity and expectations in niche-development trajectories: Ups and downs in Dutch biogas development (1973-2003). Technol. Anal. Strateg. Manag. 2006, 18, 375-392. [CrossRef]

33. Wright, E.O. Envisioning Real Utopias; Verso: London, UK, 2010.

34. Battilana, J.; Leca, B.; Boxenbaum, E. How Actors Change Institutions: Towards a Theory of Institutional Entrepreneurship. Acad. Manag. Ann. 2009, 3, 65-107. [CrossRef]

35. Hisschemöller, M.; Bode, R. Institutionalized knowledge conflict in assessing the possible contributions of $\mathrm{H} 2$ to a sustainable energy system for The Netherlands. Int. J. Hydrog. Energy 2011, 36, 14-24. [CrossRef]

36. Frantzeskaki, N.; Hölscher, K.; Bach, M.; Avelino, F. Co-Creating Sustainable Urban Futures: A Primer on Applying Transition Management in Cities; Springer International Publishing: Cham, Switzerland, 2018.

37. Hisschemöller, M.; Cuppen, E. Participatory assessment: Tools for empowering, learning and legitimating. In The Tools of Policy Formulation: Actors, Capacities, Venues and Effects; Edward Elgar: Cheltenham, UK, 2015; pp. 33-51. 
38. Van de Kerkhof, M.; Hisschemöller, M.; Spanjersberg, M. Shaping diversity in participatory foresight studies. Experiences with interactive back casting in a stakeholder dialogue on long-term climate policy in The Netherlands. Greener Manag. Int. 2002, 37, 85-99. [CrossRef]

39. Robinson, J.B. Futures under glass: A recipe for people who hate to predict. Futures 1990, $22,820-842$. [CrossRef]

40. Dreborg, K.H. Essence of backcasting. Futures 1996, 28, 813-828. [CrossRef]

41. Quist, J. Backcasting for a Sustainable Future: The Impact after 10 Years; Eburon Academic Publishers: Delft, The Netherlands, 2007.

42. Robinson, J. Future subjunctive: Backcasting as social learning. Futures 2003, 35, 839-856. [CrossRef]

43. Breukers, S.; Hisschemöller, M.; Cuppen, E.; Suurs, R. Analysing the past and exploring the future of sustainable biomass. Participatory stakeholder dialogue and technological innovation systems research. Technol. Forecast. Soc. Chang. 2014, 81, 227-235. [CrossRef]

44. Avelino, F.; Wittmayer, J.M.; Pel, B.; Weaver, P.; Dumitru, A.; Haxeltine, A.; Kemp, R.; Jørgensen, M.S.; Bauler, T.; Ruijsink, S.; et al. Transformative social innovation and (dis) empowerment. Technol. Forecast. Soc. Chang. 2017. [CrossRef]

45. Proka, A.; Beers, P.J.; Loorbach, D. Transformative Business Models for Sustainability Transitions. In Sustainable Business Models: Principles, Promise, and Practice; Moratis, L., Melissen, F., Idowu, S.O., Eds.; Springer International Publishing: Cham, Switzerland, 2018.

46. Loorbach, D.; Frantzeskaki, N.; Huffenreuter, R.L. Transition Management. Taking Stock from Governance Experimentation. J. Corp. Citizensh. Issue 2015, 58, 48-66. [CrossRef]

47. Raven, R.P.J.M. Strategic Niche Management for Biomass; Eindhoven University of Technology: Eindhoven, The Netherlands, 2005.

48. Wittmayer, J.M.; Schäpke, N. Action, research and participation: Roles of researchers in sustainability transitions. Sustain. Sci. 2014, 9, 483-496. [CrossRef]

49. Schwencke, A.M. Lokale Energie Monitor 2016; Hier Opgewekt: Utrecht, The Netherlands, 2016. (In Dutch)

50. N.V. Nuon Energy Annual Report 2017. Fossil Free within One Generation. 2018. Available online: https://www.nuon.com/globalassets/nederland/bedrijf/publicaties/nv-nuon-energy-annualreport-2017.pdf (accessed on 30 May 2018).

51. Feiten \& Cifrers Kerncijfers Essent uit het Jaarverslag Innogy SE 2016. Available online: https://www.essent. $\mathrm{nl} /$ content/overessent/dit-is-essent/feiten-en-cijfers/index.html (accessed on 30 May 2018).

52. Eneco-Maakt de Technologie van Morgen Vandaag Beschikbaar. Feiten. Available online: https://www. enecogroep.nl/wie-we-zijn/onze-merken/ (accessed on 30 May 2018).

53. Schoots, K.; Hekkenberg, M.; Hammingh, P. Nationale Energieverkenning 2016. ECN-O-16-035. Petten: Energieonderzoek Centrum Nederland 2016. Available online: http:/ /www.pbl.nl/sites/default/files/cms/ publicaties / pbl-2016-nationale-energieverkenning-2016_2070.PDF (accessed on 15 May 2017).

54. ODE Decentraal. Lokale EnergiecoöPeraties Geven Stevige Impuls aan Energietransitie in Nederland Ambitiedocument ODE Decentraal Een Oproep voor Steun van Politiek en Overheid. 2017. Available online: https:/ / www.duurzameenergie.org/f / files/download/publicaties/ambitiedocumentode-decentraal.pdf (accessed on 20 May 2017).

55. ODE Decentraal. Coöperaties Helpen Nederland van het aardgas af. 2017. Available online: https://www. duurzameenergie.org/nieuws / 2017-03-09-coperaties-helpen-nederland-van-het-aardgas-af (accessed on 20 May 2017).

56. ODE Decentraal. Postcoderoosregeling en Verlaging Belasting op Elektriciteit 2018. Available online: https: / / www.duurzameenergie.org/nieuws / 2018-06-27-postcoderoosregeling-en-verlaging-belastingop-elektriciteit (accessed on 30 June 2018).

(C) 2018 by the authors. Licensee MDPI, Basel, Switzerland. This article is an open access article distributed under the terms and conditions of the Creative Commons Attribution (CC BY) license (http://creativecommons.org/licenses/by/4.0/). 